\title{
Expression of concern: 004 Fetal outcome following dydrogesterone exposure in pregnancy
}

Koren G, Gilboa D. O04 Fetal Outcome following Dydrogesterone Exposure in Pregnancy. Arch Dis Child 2019;104:e2. doi: 10.1136/archdischild-2019-esdppp.4

The Editor-in-Chief of Archives of Disease in Childhood has been advised that the full report of this trial, published in Clinical Drug Investigation (https://doi.org/10.1007/s40261-01900862-w), has been retracted.

We do not have sufficient information about the reasons for retraction of the trial to provide evidence that this abstract is unreliable and should be retracted.

(C) Author(s) (or their employer(s)) 2021. No commercial re-use. See rights and permissions. Published by BMJ.

Arch Dis Child 2021;106:e2. doi:10.1136/archdischild-2019-esdppp.4eoc1

(D) Check for updates 